\title{
УДК 37.091.26:004
}

\section{Victoria O. Koretska}

$\mathrm{PhD}$ in Pedagogic science, Senior Lecturer in applied Mathematics, Statistics and Economy Volodymyr Vynnychenko Central Ukrainian State Pedagogical University, Kropyvnytskyi, Ukraine ORCID ID 0000-0003-1570-7669

vika.koretskaya@gmail.com,vkoretska@kspu.kr.ua

\section{Svitlana O. Shlianchak}

$\mathrm{PhD}$ in Pedagogic science, Senior Lecturer of the chair of Computer Study

Volodymyr Vynnychenko Central Ukrainian State Pedagogical University, Kropyvnytskyi, Ukraine ORCID ID 0000-0001-9893-5709

shlanchaksveta@gmail.com,sshlianchak@kspu.kr.ua

\section{USE OF MOODLE-BASED INFORMATIONAL TECHNOLOGIES FOR TEST TASKS ANALYSIS}

\begin{abstract}
Active implementation of the education controlling systems into the educational process stipulates the realization of automatic control of the level of students' training. In such circumstances, there arises an opportunity to explore integrated means which can be used to evaluate the quality of testing materials. An overview of embedded functions of the Moodle system for test analysis according to statistical characteristics is presented in the article. Empirical studies of the test on a representative sample of test takers help to evaluate the informativity of tasks. The test is formed by such a system of tasks which provides informative assessment of the level and quality of students' training. Characteristics of the test as a means of pedagogical measuring show the dependence of informational content of the test on the characteristics of test tasks and on the level of students' training. The work with the "Statistics" module is considered in detail. Pedagogical potential of built-in LMS Moodle services and their use in the educational measurement theory is shown.
\end{abstract}

Keywords: test; test task; Moodle; statistics; test analysis.

\section{INTRODUCTION}

Problem formulation. Active implementation of the education controlling systems into the educational process stipulates the realization of automatic control of the level of students' training. In such circumstances, there arises an opportunity to explore integrated means which can be used to evaluate the quality of testing materials.

It often occurs that in the process of preparing such materials the teaching staff pay their attention to the methods of creating test tasks and do not investigate whether they are appropriate for tests. So there appears a contradiction between the development of automatic test systems and the teachers' reluctance to use the tools for analyzing test content and test questions / tasks in particular.

There is a significant number of both free and proprietary software tools which allow to perform automatic test control of knowledge. These software products include the following: Hot Potatoes, MyTest, iTest, OpenTEST, TCExam, SunRav TestOfficePro, SunRav TestOfficePro, Learning Content Management System (LCMS) MOODLE and others.

This article will consider the possibility of imbedded tools for test task analysis as illustrated by the Moodle 3.0.x system. In particular, much attention will be paid to the statistical characteristics that allow analyzing test tasks, test answers and the whole test.

Analysis of recent research and publications. The research of the following scientists was devoted to implementing the Moodle system into the educational process: V.Yu. Bykov, V.M. Kukharenko [1] (the technology of creating a distance course); O.M. Anisimov, 
Yu.V. Trius, I.V. Gerasimenko, V.M. Franchuk, J. Cole, H. Foster, T. Robb, K. Brandle (peculiarities of using the system for organizing the educational process) [2], [3], [4], [5], [6]; V.P. Sergienko, V.M. Franchuk, L.O. Kukhar (methodological aspects of creating tests in the Moodle system) [7], [8], [9] and others.

Recently, the number of works related to the theoretical basics of educational measurements, the issues of classical and modern models of testing, test construction and test tasks design, as well as to the computer means of testing has increased (O.V. Avramenko, V.S. Kim, L.O. Kukhar, V.P. Sergienko, V.S. Avanesov, M.B. Chelyshkova, I.E. Bulakh, V.S. Fetisov and others) [10], [11], [12], [13], [14], [15], [7] (Fetisov, 2011, Avanesov, 2002, Avramenko, 2007, Bulakh, 1995, Chelyshkova, 2002, Kim, 2007, Serhiienko, Franchuk, Kukhar, 2014).

The objective of the article. Active integration of the educational content controlling systems into the learning process (mixed, distance learning) includes combining online courses with the standard methods and using computer tests to monitor students' academic achievement. However, there is a need to discuss improvements to the learning component that is related to the system of evaluating the level of students' academic knowledge. Therefore, the objective of the article is to characterize the tools available in the Moodle system for analyzing the structure of the test ("Statistics" item) and storing the data for further processing using other tools to analyze the test results.

\section{EMPHASIZING THE PREVIOUSLY UNSOLVED ASPECTS OF THE GENERAL PROBLEM}

This article examines the expediency of using the imbedded means of the Moodle system for analysis and processing of the test results in the Programming Course as shown by the students majoring in Computer Science. The research provides detailed information about the tools for creating a bank of test questions. Thus, it is not difficult for a user possessing the educational management skills to fill in the test with tasks. However, not being acquainted with the basics of mathematical and statistical data processing, it is difficult to assess the quality of the prepared test materials. Therefore, the article provides the instructions for interpreting the obtained results in parallel with the stages of mathematical and statistical processing of empirical data.

\section{RESEARCH RESULTS}

\section{1. Test as a means of pedagogical measuring}

A test is sometimes identified as a series of multiple-choice questions. We believe that this definition of a test is inaccurate. The author considers a test as a means of pedagogical measuring that is a tool that consists of a system of test tasks, rules for their application and evaluation, and recommendations for the interpretation of test results. We define pedagogical measuring as a process of matching between the estimated characteristics of students and the empirical scale points in which the ratio between estimated performance properties is marked by the functions of numerical series [10] (Fetisov, 2011, p. 37). Thus, test tasks appear to be units of measurement, and students are characterized according to their knowledge and skills at the time of completing the given test tasks. In this particular case, the students studying the Programming Course were the object of evaluation. The score scale of the tested participants is considered to be the result of measurement. The measuring tool is a test consisting of test tasks, which, in their turn, serve as diagnostic properties in the process of pedagogical 
diagnosis. Thus, we consider a test task to be a test component that suits the requirements for test tasks and has the required verification of statistical properties.

The tasks in the test form include those that meet the following requirements: compliance with the purpose; pithiness; logical forms of expression; availability of the space for answers; equivalence of the rules for evaluating answers; correct arrangement of the elements of tasks; availability of uniform guidelines for all test takers; and congruence of the instructions with the form and content of the task.

Empirical studies of the test based on the representative selection of test takers help to evaluate the informativity of test tasks. That is, the test is formed by such a system of tasks, which provides informative assessment of the level and quality of students' training. Defining the test as a means of pedagogical measuring shows the dependence of test informativity on the characteristics of test tasks and on the level of students' training.

\subsection{Statistical justification of test results}

Analysis of scientific literature on the processing of test results indicates the existence of two major theoretical approaches to the construction and use of educational tests: one based on the Classical Test Theory (CTT), and the other within the theory of latent-structural analysis (IRT - Item Response Theory), also called methodology of the modern theory of test design. There are professionals who clearly support one of the theories, but there are those who divide the test preparation process into two stages. At the stage of accumulating the test tasks, empirical data are worked out with the help of the classical theory, and at the stage of results analysis IRT apparatus is used. The use of statistical parameters, which are calculated using the classical theory of tests, is observed in the Moodle system [16] (Andronatii, Bolilyi, Shlianchak, 2016, p. 55).

Therefore, we will explore some of the characteristics of test tasks using the classical theory on the example of intermediate programming knowledge control among second-year students in the field of Computer Science. The test offered to students contained 19 tasks of the following types of test form: true/false statements, a short answer, multiple choice of one correct answer, multiple choice of several correct answers, matching, built-in-answers, random order of answers. The score for the test was formed as the sum of points received by a student and was transformed by the system into a scale from 0 to 5 .

To view the test results in the Moodle system and to conduct further analysis, it is necessary to activate the "Test" activity and select the "Statistics" item in the block "Administration" ("Test Control" $\rightarrow$ "Results" $\rightarrow$ "Statistics"), and then the table "Information about the test" will open in the workspace of the window (Fig. 1). This table displays the general information about the test. It should be noted that we have selected the test which is not ideal. This was done deliberately to demonstrate the process of improving the quality of the test and the test tasks.

We will present the information in the table and note in the parentheses the statistical characteristics calculated by the system: the test name, the course name, the number of complete graded first attempts (38), total number of attempts (38), the average grade of first attempts $(52.73 \%)$, the average grade of all attempts $(52.73 \%)$, the average grade of last attempts $(52.73 \%)$, the average grade of highest graded attempts $(52.73 \%)$, the median grade $(52.27 \%)$, standard deviation $(14.78 \%)$, the score distribution skewness $(0.2373)$, the score distribution kurtosis (-0.6686), the coefficient of internal consistency (47.89\%), error ratio $(72.19 \%)$, and standard error $(10.67 \%)$.

Let us characterize the obtained figures. The average grade is calculated as the average estimate of all test takers. The average values characterize the figures where the observation is concentrated, also called the central distribution tendency. Measures of the central tendency 
help in assessing the test quality under the condition of representativeness of the test participants. It is believed that a good regulatory-oriented test ensures the normal distribution of individual scores of a representative sampling of students if the average points are in the center of distribution and other scores are around the average one according to the normal law [14] (Chelyshkova, 2002, p. 232). This means that about $70 \%$ of the scores are located in the center, and others are attracted to the edges of distribution.

The average grade of first, last and all attempts, as well as the average grade of highest graded attempts - in case the students are given several attempts to pass the test, the quality dynamics will point to the growth of the average score of the last attempts in comparison with the first ones. Lack of progress can indicate that the students are not studying. The median is the average grade result of the students tested. In other words, the median is the value that divides the items of the ranked series into two equal parts.

Standard deviation is a measure of random variable value dispersion against its mathematical expectation. This index is the square root of the dispersion, and is a very useful measure of variation as it characterizes the change of value around the average result. Result variations from $12 \%$ to $18 \%$ are considered normal. If the value is smaller, this means that the grades are very close.

Quiz information

\begin{tabular}{|c|c|c|c|}
\hline \multirow[b]{2}{*}{ Download full report as } & \multicolumn{2}{|c|}{$\begin{array}{l}\text { secs ago there have been } 0 \text { attempts since then. } \\
\text { Recalculate now }\end{array}$} & \multirow[b]{3}{*}{ Тест 1} \\
\hline & Comma separated values text file & Download & \\
\hline \multicolumn{2}{|l|}{ Quiz name } & & \\
\hline \multicolumn{2}{|l|}{ Course name } & & Програмування \\
\hline \multicolumn{2}{|c|}{ Number of complete graded first attempts } & & 38 \\
\hline \multicolumn{2}{|c|}{ Total number of complete graded attempts } & & 38 \\
\hline \multicolumn{2}{|c|}{ Average grade of first attempts } & & $52.73 \%$ \\
\hline \multicolumn{2}{|c|}{ Average grade of all attempts } & & $52.73 \%$ \\
\hline \multicolumn{2}{|c|}{ Average grade of last attempts } & & $52.73 \%$ \\
\hline \multicolumn{2}{|c|}{ Average grade of highest graded attempts } & & $52.73 \%$ \\
\hline \multicolumn{2}{|c|}{ Median grade (for highest graded attempt) } & & $52.27 \%$ \\
\hline \multicolumn{2}{|c|}{ Standard deviation (for highest graded attempt) } & & $14.78 \%$ \\
\hline \multicolumn{2}{|c|}{ Score distribution skewness (for highest graded attempt) } & & 0.2373 \\
\hline \multicolumn{2}{|c|}{ Score distribution kurtosis (for highest graded attempt) } & & -0.6686 \\
\hline \multicolumn{3}{|c|}{ Coefficient of internal consistency (for highest graded attempt) } & $47.89 \%$ \\
\hline \multicolumn{3}{|c|}{ Error ratio (for highest graded attempt) } & $72.19 \%$ \\
\hline \multicolumn{3}{|c|}{ Standard error (for highest graded attempt) } & $10.67 \%$ \\
\hline
\end{tabular}

Fig. 1. Information about the test

Score distribution skewness indicates the degree of deviation of the empirical distribution from the symmetrical one, that is typical of the normal curve. If skewness is zero, the test is considered to be well-balanced in terms of complexity. A negative or positive skewness indicates a rather easy or complicated test, respectively. In our case, the skewness score is positive and equal to 0.2373 , indicating that the test is satisfactory in terms of complexity. Thus, if the distribution skewness is positive, the majority of students received grades higher than the average score; and if the distribution skewness is negative, the students are below the average score.

Score distribution kurtosis points to the form of the peak of distribution. The curve with a sharp peak has positive kurtosis, the curve with a flat peak has negative kurtosis, and the curve with the average peak has zero kurtosis. In the example seen from Fig.1, the kurtosis 
value is -0.6686 , which means that the test results are highly scattered around the average score.

Coefficient of internal consistency makes it possible to evaluate the homogeneity degree of the test tasks and their congruence with the test. This characteristic feature of the test is closely related to the concept of test validity (validity of the test tasks, the testing procedure, and the evaluation procedure), which is defined both by measurement parameters and procedures and by the characteristics of the studied quality. Connections existing between the test tasks can be detected during testing by means of correlation. If the test tasks have a significant correlation with the test result and minimally correlate with one another $\left(r_{X Y} \leq 0,3\right)$, the test reaches the maximum validity. High correlation of the test tasks indicates that the test is overloaded with overlapping tasks (unequivocal tasks). If the value is below $64 \%$, the test is unsatisfactory as such, and the validity of its tasks has to be reconsidered. The test should approximate the level when each separate test task correlates with the test in general and retains minimal correlation with other test tasks.

Error ratio indicates the value divergence of the studied quality, that is how some students are better than the others and how many random variations are revealed. The smaller the number of random variations, the better is the test. The values exceeding $50 \%$ are considered unsatisfactory because they point to a higher degree of randomness in the test result.

Standard error is the standard deviation of the grades obtained from repeated random sampling. The less significant is the standard error, the more precise the score of the test will be. If the value is considerably higher than $8 \%$, it is quite probable that a large number of students are assessed in a wrong way, and their grades do not reflect their knowledge.

Any deviation from the normal value means that each test task must be analyzed separately and in detail. The Moodle system provides opportunities for a more detailed analysis of the test structure and the statistical characteristics of each test task (Fig. 2). Let us consider each of the elements from the table of test structure analysis.

Numbers of questions are unique numbers of test tasks. Test task type is presented as an icon. Viewing and editing questions allows to look through and introduce changes to the content of a test task. Also it should be noted that while viewing the question one can answer it, send it for evaluation and get the result (this action may be done an unlimited number of times). A short question name is a hyperlink that leads to a page with the analysis of answers to the selected test task. Attempts indicator shows the number of answers to the test task.

Facility index shows the complexity of the test task and is calculated as the percentage (the quotient) of correct answers. Only empirical indicators of complexity have been considered in the classical theory of testing for many years. In modern test theories, more attention is focused on the character of mental activity during the completion of different test tasks.

Progress indicators are important for the successful use of tests. If a test has a lot of complex tasks, its validity and reliability are reduced greatly. If a test has very simple tasks, the test will be monotonous and ineffective. Therefore, complex tasks are those where the success rate is below $20 \%$, and in extremely simple tasks it exceeds $80 \%$. In case of absolute or zero task progress it is withdrawn from the test. If the value is $100 \%$, a given test task is very simple, so all the students give correct answers to this question. $0 \%$ value means no students have given the correct answer, so the test task is too complex. In both cases, the test task has to be removed from the test or reconsidered. A more detailed interpretation of the progress index of a test task looks as follows: an extremely complex test task or an incorrectly formulated task $(0 \%-5 \%)$, a very complex task $(6 \%-10 \%)$, a complex test task $(11 \%$ $20 \%)$, a relatively complex test task $(20 \%-34 \%)$, a test task of average complexity $(35 \%$ - 
$64 \%)$, a relatively simple test task $(66 \%-80 \%)$, a simple task $(81 \%-89 \%)$, a very simple task $(90 \%-94 \%)$, an extremely simple task $(95 \%-100 \%)$.

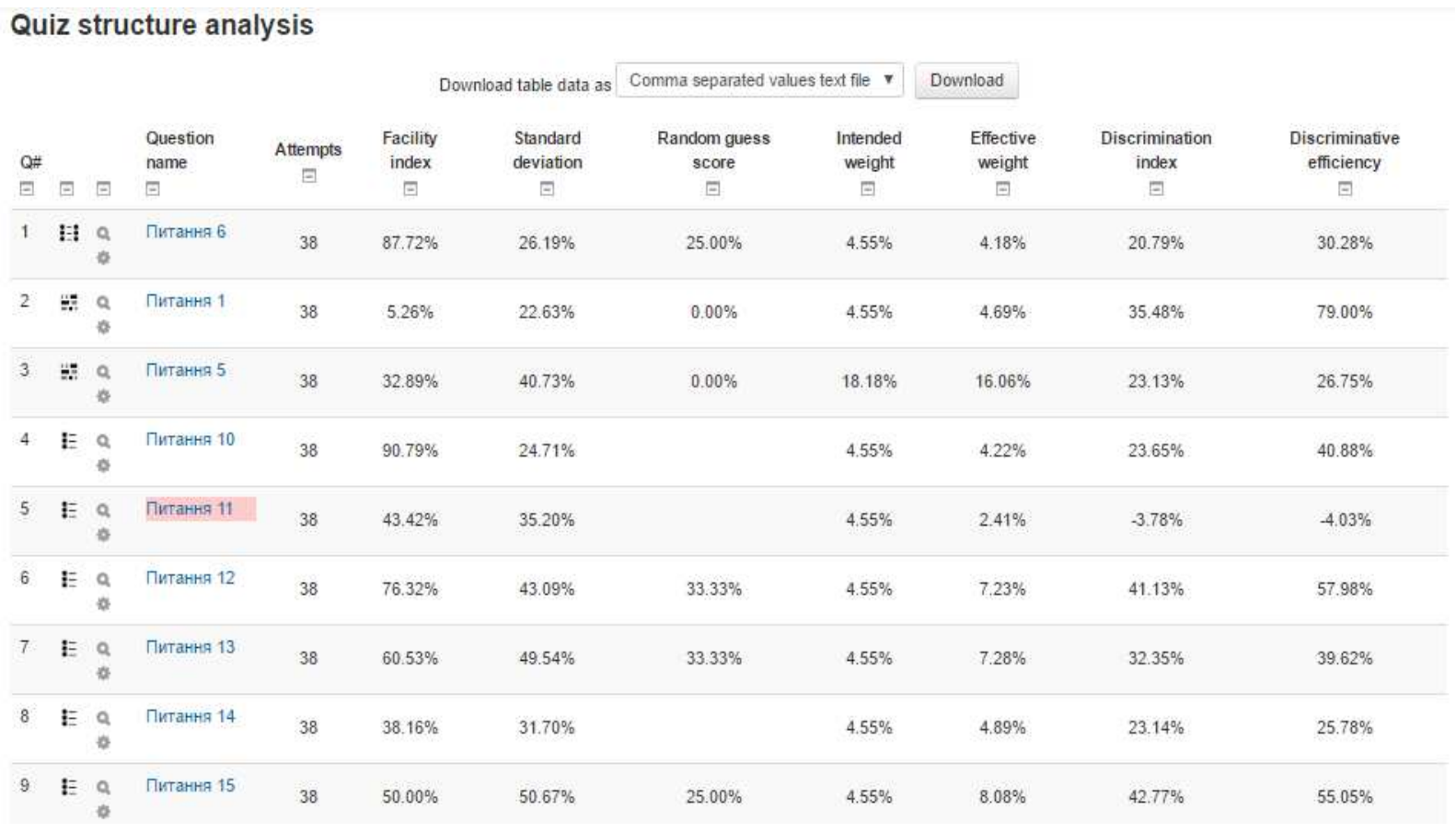

Fig. 2. Test structure analysis

Standard deviation should not acquire zero or low values because it demonstrates the low differential ability of the test task. This task makes it impossible to distinguish students in the group according to their preparation. Zero indicator of success will be shown if all the students gave the same answer. A higher differential ability of the test tasks points to the higher quality of the test. In accordance with the requirements of the pedagogical measurement theory, the index of standard deviation must exceed or be equal to $30 \%$. The tasks where the index is below $30 \%$ are deleted from the test.

Random guess score is an average grade which could be expected if a student answered the question at random. These assumptions are only possible for multiple choice tests. For example, a multiple choice test task with one correct answer out of four suggested options would have the random guess score of $25 \%$. If there are five options of the answer, the random guess score equals $20 \%$.

Intended weight characterizes the weight of a test task as percentage out of the total test score (all tasks may have equal weight). Thus, if the test tasks are intended to be of different complexity, just as the expected score, the intended weight will also differ.

Effective weight of a test task is an indicator which is based on test results. An absolutely successful task has zero effective weight. Discrimination index and Discriminative efficiency (coefficient of discrimination) of the test task concern the characteristics that show the ability of the task to differentiate students as worse or better. Therefore, a high rate of discrimination is characteristic of a successful test which makes it possible to divide the group of test participants into strong and weak students. The tasks with close to zero or negative indexes (all the test participants from the strong group and all the members of the weak group have given correct answers) are removed from the test. The task with an absolute discrimination index value indicates that all the students from the strong group answered it correctly, and the participants of the weak group gave wrong answers. The literature on educational measurements suggests the following interpretation of discrimination index 
values: the task functions satisfactorily $\left(D_{j} \geq 40 \%\right)$; the task needs a slight correction or there is no need to improve it $\left(30 \% \leq D_{j} \leq 39 \%\right)$; the task must be reviewed $\left(20 \% \leq D_{j} \leq 29 \%\right)$; the task should be removed from the test or paraphrased completely $\left(D_{j} \leq 19 \%\right)$ [12] (Avramenko, 2007, p. 144). Discriminative efficiency as opposed to Discrimination index is more effective for determining the quality of tests. The discriminative efficiency index accounts for all the results of the test participants rather than just the results of the strong and weak groups.

Comparison of the facility index and the discriminative efficiency can be represented graphically as seen from Fig. 3 .

Statistics for question positions

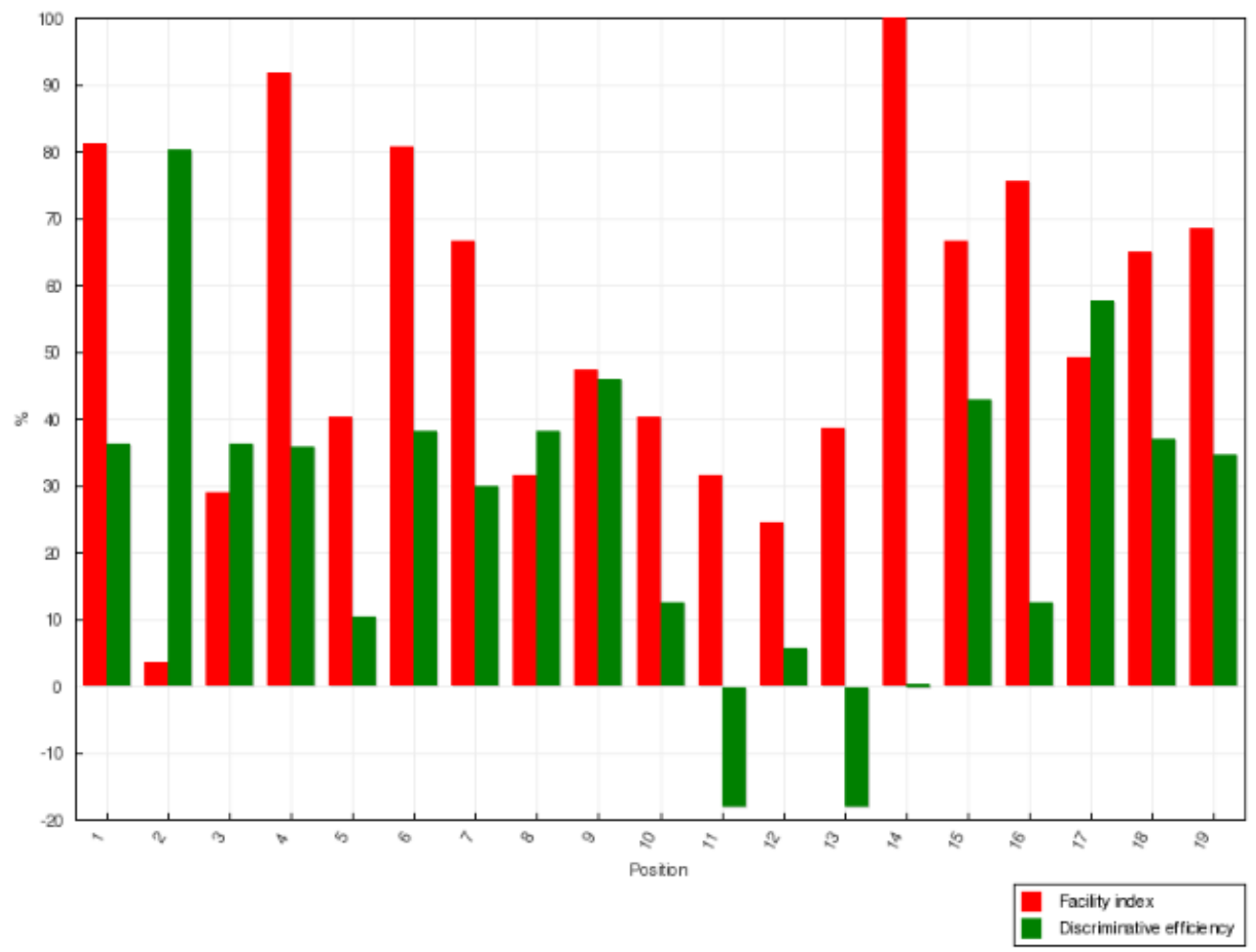

Fig. 3. The bar graph comparing facility index and discriminative efficiency

The teacher can save the table with the test results for further use and analysis. To do this, one should choose the file format in which the data will be downloaded.

\section{CONCLUSIONS AND FURTHER RESEARCH}

In the process of thorough analysis of Ukrainian and foreign scientific literature on the research problem, it was found that most users of LCMS Moodle (course authors, lecturers) pay attention to methods of creating test tasks and questions while preparing the materials of the course, but do not examine them for compliance with the test standards. The scientific research suggests the ways to collect empirical test results, the review of mathematical and statistical data processing, and the interpretation of results.

The study results confirmed that the analysis of the test tasks constructed in the Moodle system is an effective and optimal way to monitor the quality of prepared tests. We managed 
to identify the stages of improving the test: analysis of the test in general; defining statistical characteristics of each test task; making a decision on editing or deleting a test task from the test; analysis of answers to each test task. Judging from what has been mentioned above, the introduction of testing on the basis of the Moodle system allows to objectively identify the students' academic achievements and significantly increase control effectiveness.

In the process of determining the statistical characteristics of a test, it was proposed to graphically analyze the obtained data and present them in the form of bar graphs. Our personal experience suggests that it is convenient to save the test results in a separate file for further analysis of the data.

It seems prospective to study the possibilities to improve the assessment of students' academic achievements using other theories for analyzing test results, the IRT in particular. Interpretation of the statistical characteristics provided by the system is an impetus for an indepth study of the issues related to educational measurements.

The article refers to the test results obtained while teaching the "Programming" course, which can be viewed with guest access on the Moodle CSPU website (http://moodle.kspu.kr.ua/course/view.php?id=89).

\section{REFERENCES}

[1] Bykov, V. \& Kukharenko, V. (2008). The technology of creating a distance learning course. Kyiv: Millennium. (in Ukrainian)

[2] Anisimov, A. (2009). Working in the distance learning Moodle system. Kharkov, KhNAGH. (in Russian)

[3] Tryus, Yu. \& Herasymenko, I. \& Franchuk, V. (2012). Moodle-based electronic learning system in higher educational establishments. Cherkasy. (in Ukrainian)

[4] J. COLE, and H. Foster, Using Moodle, Second Edition. Teaching with the popular open source course management system. Sebastopol, CA: O’Reilly Community Press, 2007. (in English)

[5] T. Robb, "Moodle: A virtual learning environment for the rest of us", TESL-EJ, no. 8(2), pp. 1-8, 2004. (in English)

[6] K. Brandle, "Are you ready to Moodle?", Language Learning Technology, no. 9(2), pp. 16-23, 2005. (in English)

[7] Serhiienko, V. \& Franchuk, V. \& Kukhar, L. (2014) Guidelines for creating test tasks and tests in the MOODLE system of managing educational materials. Kyiv: M.P.Dragomanov NEA. (in Ukrainian)

[8] Kukhar, L. \& Serhiienko V. (2010). Test construction. Lectures. Lutsk. (in Ukrainian)

[9] A. Blanco, G. Ginovart "On How Moodle Quizzes Can Contribute to the Formative e-Assessment of First-Year Engineering Students in Mathematics Courses", RUSC. Revista de Universidad y Sociedad del Conocimiento, vol. 9, no. 1, pp. 355-370, 2012. (in English)

[10] Fetisov, V. (2011). Computer technologies in testing. Nizhin: Publisher PE Lysenko M. (in Ukrainian)

[11] Avanesov, V. (2002). Test tasks creation. A textbook for university, college and technical school lecturers, school teachers, gymnasium and lyceum teachers, students and post-graduate students of pedagogical universities. Moscow: Testing Center. Moscow: (in Russian)

[12] Avramenko, O. V. (Ed.) (2007). Measurement in Education. Kirovohrad, Lysenko V.F. (in Ukrainian)

[13] Bulakh, I. Ye. (1995) Theory and methodology of computer-based testing of learning success (based on medical schools). Dr. ped. sci. dissertation, Kyiv Taras Shevchenko National University, Kyiv, Ukraine. (in Ukrainian)

[14] Chelyshkova, M. (2002). Theory and practice of designing pedagogical tests. Moscow: Logos. (in Russian)

[15] Kim, V. (2007). Testing of educational achievements. Ussuriysk, Publishing house USPI, 2007. 214 p. (in Russian)

[16] Andronatii, P. \& Bolilyi, V. \& Shlianchak, S. (2016). Development of distance learning courses by means of KSPU wiki, cloud-KSPU and Moodle-KSPU. Kirovohrad: V.Vynnychenko KSPU. (in Ukrainian) 


\title{
ВИКОРИСТАННЯ ІНФОРМАЦІЙНИХ ТЕХНОЛОГІЙ ДЛЯ АНАЛІЗУ ТЕСТОВИХ ЗАВДАНЬ НА БАЗІ СИСТЕМИ МООDLЕ
}

\author{
Корецька Вікторія Олександрівна \\ кандидат педагогічних наук, старший викладач кафедри прикладної математики, статистики та \\ економіки \\ Центральноукраїнський державний педагогічний університет імені Володимира Винниченка, \\ м. Кропивницький, Україна \\ ORCID ID 0000-0003-1570-7669 \\ vika.koretskaya@gmail.com,vkoretska@kspu.kr.ua \\ Шлянчак Світлана Олександрівна \\ кандидат педагогічних наук, старший викладач кафедри інформатики \\ Центральноукраїнський державний педагогічний університет імені Володимира Винниченка, \\ м. Кропивницький, Україна \\ ORCID ID 0000-0001-9893-5709 \\ shlanchaksveta@gmail.com,sshlianchak@kspu.kr.ua
}

\begin{abstract}
Анотація. Активне впровадження в освітній процес систем управління навчанням передбачає реалізацію автоматизованого контролю рівня підготовки студентів. У таких умовах відкривається можливість вивчення вбудованих засобів, які можна використовувати для оцінювання якості тестових контрольно-вимірювальних матеріалів. У статті представлено огляд вбудованих можливостей системи Moodle для проведення аналізу тесту за статистичними характеристиками. Детально розглянуто роботу з модулем «Статистика». Показано педагогічний потенціал вбудованих механізмів LMS Moodle та їх використання в теорії освітніх вимірювань. Розглянуто ключові функціональні аспекти, які необхідно враховувати у процесі вдосконалення тестових завдань і підвищення їх якості. Розкрито зміст понять: середня оцінка, медіана, стандартне відхилення, асиметрія розподілу, ексцес розподілу, коефіцієнт внутрішньої узгодженості, співвідношення помилок, стандартна помилка. Також охарактеризовано, як інтерпретувати такі показники: успішність, стандартне відхилення, оцінка навмання, призначена вага, ефективна вага, розрізнення, ефективність розрізнення. У статті було використано дані проведеного тестування студентів у курсі «Програмування», який можна переглянути в гостьовому доступі на сайті Moodle ЦДПУ.
\end{abstract}

Ключові слова: тест; тестове завдання; Moodle; статистика; аналіз тесту.

\section{ИСПОЛЬЗОВАНИЕ ИНФОРМАЦИОННЫХ ТЕХНОЛОГИЙ ДЛЯ АНАЛИЗА ТЕСТОВЫХ ЗАДАНИЙ НА БАЗЕ СИСТЕМЫ МООDLЕ}

\author{
Корецкая Виктория Александровна \\ кандидат педагогических наук, старший преподаватель кафедры прикладной математики, статистики и \\ экономики \\ Центральноукраинский государственный педагогический университет имени Владимира Винниченка, \\ г. Кропивницкий, Украина \\ ORCID ID 0000-0003-1570-7669 \\ vika.koretskaya@gmail.com,vkoretska@kspu.kr.ua \\ Шлянчак Светлана Александровна \\ кандидат педагогических наук, старший преподаватель кафедры информатики \\ Центральноукраинский государственный педагогический университет имени Владимира Винниченка, \\ г. Кропивницкий, Украина \\ ORCID ID 0000-0001-9893-5709 \\ shlanchaksveta@gmail.com, sshlianchak@kspu.kr.ua
}

Аннотация. Активное внедрение в образовательный процесс систем управления обучением предусматривает реализацию автоматизированного контроля уровня подготовки студентов. В таких условиях открывается возможность изучения встроенных средств, которые можно использовать для оценки качества тестовых контрольно-измерительных материалов. В 
статье представлен обзор возможностей системы Moodle для проведения анализа теста по статистическим характеристикам. Подробно рассмотрена работа с модулем «Статистика». Показано педагогический потенциал встроенных средств LMS Moodle и их использования в теории образовательных измерений. Рассмотрены основные функциональные аспекты, которые нужно учитывать в процессе усовершенствования тестовых заданий и повышения их качества. Раскрыто содержание понятий: средняя оценка, медиана, стандартное отклонение, асимметрия распределения, эксцесс распределения, коэффициент внутренней согласованности, соотношение ошибок, стандартная ошибка. Также акцентировано внимание на интерпретации таких показателей: успеваемость, стандартное отклонение, оценка наугад, назначенный вес, эффективный вес и др. В статье используются данные проведенного тестирования студентов в курсе «Программирование», который можно просмотреть в гостевом доступе на сайте Moodle ЦГПУ.

Ключевые слова: тест; тестовое задание; Moodle; статистика; анализ теста.

\section{(c) BY-NC-SA}

This work is licensed under Creative Commons Attribution-NonCommercial-ShareAlike 4.0 International License. 